\title{
Determination and Verification of the Key Assessment Indicators for the Insurance Market by Applying the Decomposition Multi-attribute Methods and Regression Analysis
}

\author{
Martina Borovcová1, Adéla Špačková ${ }^{2}$ \\ ${ }^{1}$ VŠB - TU Ostrava \\ Faculty of Economics, Department of Finance \\ Sokolská třída 33, 70200 Ostrava, Czech Republic \\ E-mail: martina.borovcova@vsb.cz \\ 2 VŠB - TU Ostrava \\ Faculty of Economics, Department of Finance \\ Sokolská třída 33, 70200 Ostrava, Czech Republic \\ E-mail: adela.spackova@vsb.cz
}

\begin{abstract}
The aim of the article is to determine and verify the key assessment indicators for the insurance market by applying the decomposition multi-attribute methods and regression analysis. The assessed specific indicators are qualitative indicators (insurance penetration, claim ratio) and quantitative indicators (gross premium, insurance benefit, number of insurance contracts, number of settled insurance claims, number of employees, number of commercial insurance companies, concentration of the insurance market, and more). The decomposition multi-criteria AHP method (analytic hierarchy process) and ANP method (analytic network process) based on the Saaty pair comparison approach are described, including the computation procedure. The described methods are then applied to determine the preferences of the indicators for the insurance market. Subsequently, a particular regression model is created. Our findings reveal the resulting preferences of individual indicators of the insurance market evaluation and key assessment indicators.
\end{abstract}

Keywords: insurance market, key assessment indicators for the insurance market, multi-attribute decomposition methods, analytic hierarchy process, regression analysis

JEL codes: CO2, C4, G2, G11

\section{Introduction}

Insurance plays a key role in supporting the economic activity and a sound insurance mechanism makes a critical contribution to the sustainability and growth of the national economy. Few individuals and entities can effectively protect their property ownership and other economic rights without relying on insurance. Insurance companies are also significant institutional investors playing a significant role in providing financing to the real economy through investments in bonds, stocks and other assets (Kwon and Wolfrom, 2016). 
The insurance industry is one of the most important sectors of the economy. The insurance market is very much intertwined in the financial markets; therefore, an assessment of its level is important. The assessment and analysis of the insurance market is done using selected indicators. However, since the importance of the indicators is different, there is a need to identify the key, the most important, indicators. For this purpose, multi-criteria decision-making methods can be used. Specifically, methods for the determination of criteria preference.

Multi-criteria decision-making is one of the ways to choose the optimum option out of sets of options. Only very rarely it is possible to find the optimum option which meets all criteria specified. The solution for the decision-making problem is more often a compromise option, which meets just the most important criteria and does not meet all the specified criteria. It is preferable to take into account more than one decision-making criterion when making the decision. However, there are situations in which a single evaluation criterion has been used. Conditions for the quantitative nature of the criteria would then be enough to organize an option according to the values of the criteria and the option with the highest or the lowest value would be the best (optimum) option. Still, there are relatively a few decisionmaking problems with a mono-criteria character. More and more frequently it is necessary to deal with problems in which the solution options should be assessed using a larger number of evaluation criteria. Such decision-making problems then have the character of multi-criteria decision-making.

The aim of this article is to determine and verify the key assessment indicators for the insurance market by applying the decomposition multi-attribute methods and regression analysis. The assessed specific indicators are qualitative indicators (insurance penetration, claim ratio) and quantitative indicators (gross premium, insurance benefit, number of insurance contracts, number of settled insurance claims, number of employees, number of commercial insurance companies, concentration of the insurance market, and more). The decomposition multi-criteria AHP method (analytic hierarchy process) and ANP method (analytic network process) based on the Saaty pair comparison approach are described, including the computation procedure. The described methods are then applied to determine the preferences of the indicators for the insurance market. Subsequently, a particular regression model is created.

Setting the preference of the indicators, both on subjective and objective bases, including the creation and verification of the particular model, makes the evaluation of the insurance market innovative, unprecedented and highly topical.

\section{Literature Review}

The very existence, as well as the effective functioning of insurance, is now necessary. And just as important is to watch the development of the insurance market. Insurance market activity, both as financial intermediary and as a provider of risk transfer and indemnification, may promote economic growth by allowing 
different risks to be managed more efficiently. This activity would encourage the accumulation of new capital and mobilize domestic savings into productive investments. In this context, the facts mentioned above raises questions regarding the impact that a faster growth of insurance activity would have on economic growth (Arena, 2008). Similarly, Pradhan, Arvin and Norman (2015) looked at the development of the insurance market. Their results reveal that insurance market development specifically and financial market development overall, both seem to be long-term causative factors of economic growth.

The research into the analytic tools used was carried out by Kwon and Wolfrom (2016). In particular, they examined analytic tools used by regulators and supervisors of insurance markets. The set of analytic tools each of them uses reflects the country's specific context in terms of the level of home insurance market development, number of operating companies, number of contracts, premiums written, penetration, density, and other factors.

The first study of the decision-making theory can be found in the paper written by Daniel Bernoulli focused on utility theory, published in 1838 (Bernoulli, 1954). The multi-criteria aspect of selecting various criteria is mentioned by Vilfredo Pareto, the Italian economist, who formulated the Pareto optimality in his Manuale di Economia Politica in 1906 (Pareto, 1971).

Since the 1950's, the expansion of multi-criteria decision making has been growing exponentially and more specific publications have been published. The most famous and nowadays the most respected work is a series of books aimed at multi-criteria decision making by Thomas L. Saaty. Fundamentals of the decision-making process, especially the beginning of AHP, are well described (Saaty, 1980). This monograph is an outcome of many years of research into a very practical and simple way to facilitate decision making. As we know, there are two ways to make decisions: the analytic and the natural. Saaty called this process Analytic Hierarchy Process (AHP) (Saaty, 2006). The natural way means that a decision-maker chooses the optimum option analytically with their own experience. The issue of the Analytic Network Process has been well described in a publication called Theory and applications of the analytic network process: decision making with benefits, opportunities, costs, and risks (Saaty, 2009). The ideas in this book are guaranteed to expand consciousness about decision making and ability to understand the basic ideas (Saaty, 2010) it is basically a kind of AHP generalization. The difference compared to the previous method is between dependence and feedback. The new paradigm of our times is the interconnection between almost everything and the flow of influence among them. The connections can be physical, mental, spiritual, and others. The Analytic Network Process (ANP) gives us a different point of view of knowledge comparing intensities of preference (Saaty, 2012). A synergic effect of both methods is obvious: they can bring together diverse groups of decisionmakers with different perspectives to make a complex decision at the same time (Saaty, 2009). 
In the last two decades, the development of the above mentioned methods has led to the genesis of stochastic and fuzzy versions (Zmeškal, Dluhošová and Tichý, 2013). Other authors dealt with multi-criteria decision-making, e.g. Ramík (1999). His book is primarily focused on the detailed description of AHP and one chapter is devoted to the extension of the AHP methods, including their application. Other authors are Zmeškal (2009) and Fotr, Dědina and Hrůzová (2010).

The topics of regression analysis can be found in Hančlová (2015). This book is concerned with optimization problems in the real world. It not only described traditional decision making, it provided deeper analysis of traditional and specific factors and led to improved management.

Our previous research dealing with the problem mentioned focused on the importance of indicators of preferences for determining the level of the insurance market using the method of multi-attributes of decomposition of AHP and ANP (Borovcová and Špačková, 2017). The subject of our research is now the innovative use of decomposition methods of multi-criteria decision-making and regression analysis because the insurance market is commonly evaluated by indicators, yet the intensity of their significance has not been paid much attention.

\section{Methodology and Data}

The aims of the application of the multi-criteria decision making evaluation of the options are primarily to find the best (optimum) option and order these options from the best to the worst (Pareto, 1906). The best alternative is usually the compromise option. The compromise solution is the least distant one from the ideal alternative, or the one furthest away from the basal alternative, while the ideal alternative is the one that has all the criteria with the best possible value (Saaty, 1980). On the contrary, the option with the worst values of the criteria is the basal alternative. Ideal and basal alternatives are usually hypothetical. If the ideal alternative really existed, it would be at the same time the optimum alternative. However, this situation does not usually occur and therefore any selected solution is a solution of the compromise. The compromise option must be undominated in all tasks, which means that there is no dominating option among decision-making options (Ramík, 1999). The role of multi-criteria decision making can be classified by the type of information that expresses the preference criteria of options, see Figure 1.

Depending on the combination of the method of preference criteria determination and the values of criteria, a variety of methods can be used. Apparently, it is possible to define four groups of combinations. Group I contains tasks regardless of the preferences of the criteria, group II is represented by roles with quantitatively specified criteria (e.g., financial, economic), group III includes tasks for which both preferences of criteria and values of criteria are determined using the same method, and group IV encompasses other combinations. 
Figure 1 Multi-Criteria Decision Making Combination of the Ways of Determining the Values and Preferences of the Criteria

\begin{tabular}{|c|c|c|c|c|c|c|c|c|}
\hline \multirow{3}{*}{\multicolumn{4}{|c|}{$\begin{array}{l}\text { The combination of the } \\
\text { methods of determining the } \\
\text { values and preferences of the } \\
\text { criteria }\end{array}$}} & \multicolumn{5}{|c|}{ Preference sub-criteria } \\
\hline & & & & \multirow{3}{*}{$\begin{array}{c}\text { without } \\
\text { A }\end{array}$} & \multirow{3}{*}{$\begin{array}{c}\text { ordinal } \\
\text { sequence } \\
\text { B }\end{array}$} & \multirow{3}{*}{$\begin{array}{c}\text { cardinal } \\
\text { point } \\
\text { C }\end{array}$} & \multicolumn{2}{|c|}{ paired } \\
\hline & & & & & & & Fuller & Saaty \\
\hline & & & & & & & D & $\bar{E}$ \\
\hline \multirow{5}{*}{ 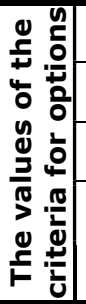 } & cardinal & quantitative & $\bar{a}$ & \multirow{5}{*}{ I } & \multicolumn{4}{|c|}{ II } \\
\hline & ordinal & sequence & b & & III & & \multirow{2}{*}{\multicolumn{2}{|c|}{ IV }} \\
\hline & cardinal & point & C & & & III & & \\
\hline & \multirow{2}{*}{ paired } & Fuller & d & & \multirow{2}{*}{\multicolumn{2}{|c|}{ IV }} & III & \\
\hline & & Saaty & e & & & & & III \\
\hline
\end{tabular}

Source: Zmeškal (2009).

One of the groups of multi-attribute methods are multi-stage decomposition methods based on Saaty's method of paired comparison. These include AHP method and ANP methods. Using these methods, preferences (weights) are determined as gradual decomposition. AHP method is linear and without feedback. ANP method is a nonlinear and complicated method with the feedback included. It allows us to capture the relationship between the variants and preferences even in the complexity of variations. AHP method is a special case (a subset) of the ANP method.

\subsection{Criteria and Methods of Determining the Values of the Criteria}

Alternatives to solving the decision problem are specified using options. The choice of the appropriate option is feasible through the evaluation criteria. Determination of the criteria is a difficult process, which requires certain knowledge of the area. The criteria used to select the most appropriate options can be classified according to several aspects. It is possible to divide the criteria into the maximizing (income, profit) and the minimizing (cost, loss), based on the level of desirable values. By the type it is possible to divide criteria into qualitative and quantitative ones. These are expressed in units of measurement.

For calculations and comparison, it is usually desirable for specified criteria values $y_{i j}$ to be normalized by the unit interval, i.e.

$$
x_{i j} \in[0 ; 1]
$$

Generally, it is possible to obtain these values of the criteria from the sub-functions of the utility (value) as:

$$
x_{i j}=u\left(y_{i j}\right)
$$


Applicability of the criteria which acquire the worst values is equal to 0 or close to 0 , and the applicability of the criteria with the best value is equal to 1 .

Saaty's AHP and ANP methods will be used in the application part of the study, therefore, the following description will focus on these methods.

\section{Saaty's Method of Pairwise Comparison}

The application of Saaty's method can be divided into two steps. The first step consists of a pairwise comparison when finding the preferential relations of criteria pairs. A so-called Saaty matrix $S$ is constructed. This matrix is symmetric with elements $s_{i j}$. It is possible to also determine the size of preference expressed by a certain number of points from the selected point scale in addition to the direction of the preference of a pair of criteria. The scale of relative importance (descriptors) was recommended by Saaty and it is shown in Table 1. Other values can be used to express sub-preferences. The strength of preferences is expressed in the interval $s_{i, j} \in[0 ; 9]$. The purpose of this step is to obtain the right upper triangular part of the matrix $S$. The diagonal element has to be $s_{i, j}=1$ and for the inverse elements (in the lower left triangular part of the matrix) the following is true:

$$
s_{i, j}=\frac{1}{s_{j, i}} .
$$

The elements $s_{i, j}$ of Saaty matrix are estimated as shares of weights of criteria $v_{i}$ and $v_{j}$, so:

$$
s_{i, j} \cong \frac{v_{i}}{v_{j}} .
$$

The scales can be obtained in the following manner:

$$
\min F=\sum_{i}^{n} \sum_{j}^{n}\left(s_{i, j}-\frac{v_{i}}{v_{j}}\right)^{2}
$$

with the condition $\sum_{i}^{n} v_{i}=1$.

Because of the difficulty, it is possible to obtain the weights using an algorithm based on the geometric average.

$$
\min F=\sum_{i=1}^{n} \sum_{j>i}^{n}\left[\ln s_{i, j}-\left(\ln v_{i}-\ln v_{j}\right)\right]^{2},
$$


with the condition $\sum_{i}^{n} v_{i}=1$.

The final solution is based on the geometric mean of rows (Saaty, 2010):

$$
w_{i}=\frac{v_{i}}{\sum_{i}^{N} v_{i}}=\frac{\left[\prod_{j}^{N} s_{i, j}\right]^{\frac{1}{N}}}{\sum_{i}^{N}\left[\prod_{j}^{N} s_{i, j}\right]^{\frac{1}{N}}},
$$

Table 1 Recommended Point Scale with the Descriptors by Saaty

\begin{tabular}{cr}
\hline The points & Descriptor \\
\hline $\mathbf{1}$ & Elements A and B are equally important \\
\hline $\mathbf{2}$ & Element A is moderately more important than element B \\
\hline $\mathbf{4}$ & Element A is strongly more important than element B \\
\hline $\mathbf{5}$ & Element A is very strongly more important than element B \\
\hline
\end{tabular}

Source: Saaty (2006), authors' own processing.

A sign of relevant evaluation is the consistency of Saaty's matrix, in other words, when the elements best satisfy the condition of transitivity. It needs to be emphasized that in many methods this aspect is not accounted for. The consistency can be measured using the coefficient of consistency $C R$ (Consistency Ratio). The coefficient for consistent evaluation should be $C R \leq 0,1$. The consistency ratio is calculated as follows: $C R=\frac{C I}{R I}$, where $=\frac{\lambda_{\max }-N}{N-1}$, (Saaty, 2010). The characteristic number of the matrix $\lambda_{\max }$ can be determined by various procedures. One option is $\lambda_{\max }=\frac{1}{N} \sum_{i}^{N}(S \cdot w)_{i} / w_{i}$, while $w$ is a vector and $(S \cdot w)_{i}$ is the $i$-th element of the vector. Further, $R I$ (Random Index) is derived from an empirical examination and reaches the following values depending on the number of criteria, see Table 2.

Table 2 Value RI according to the number of criteria

\begin{tabular}{|c|c|c|c|c|c|c|c|c|c|c|c|c|c|}
\hline $\mathbf{N}$ & 1 & 2 & 3 & 4 & 5 & 6 & 7 & 8 & 9 & 10 & 11 & 12 & 13 \\
\hline RI & 0.00 & 0.00 & 0.52 & 0.89 & 1.11 & 1.25 & 1.35 & 1.40 & 1.45 & 1.49 & 1.51 & 1.54 & 1.56 \\
\hline
\end{tabular}

Source: Saaty (2009), authors' own processing

\section{Multi-Attribute Methods AHP and ANP}

In the case of decomposition tasks, weights or values of criteria are set by gradual decomposition of the goal, global groups of criteria, sub-groups, to the initial sub- 
criteria and options. The linkages may be linear for AHP method and of a pyramid shape, or nonlinear with a feedback for the ANP method. Evaluation of preferences (weights) of the criteria is carried out using the Saaty's method of pairwise comparison.

Local weights (preferences) of the subgroups or indicators with regard to the specified purpose are determined using Saaty's method of pairwise comparison. The next step is the calculation of the global weights including the initial subweights. The sum of all sub-weights is equal to one.

In AHP, both analytic procedure and the method of supermatrix can be used. In $A N P$, it is possible to calculate global weights using only the method of supermatrix (Saaty, 2010).

In the analytic method AHP, the indicator subgroup weights are obtained as follow $w_{i, j}=v_{i} \cdot v_{i, j}$, where $w_{i, j}$ is global weight of $j$-th indicator and $i$-th group, $v_{i}$ is the local weight of $i$-th group and $v_{i, j}$ is the local weight of $j$-th indicator and $i$-th group. In this way, we can gradually get all the global weights of primary indicators.

The procedure for the calculation of weights in the case of AHP and ANP supermatrix method can be divided into three steps:

- $\quad$ First step is the determination of default supermatrix $W$. The local weights $v_{i, j}$ are typed to the columns inside this supermatrix $W$. The weights of criteria are highlighted from $e_{2,1}$ to $e_{2, n 2}$ according to the purpose (criteria) $e_{1,2}$.

- Subsequently, the default supermatrix is transformed into the weighted supermatrix $\bar{W}$ so that the sums of columns equal 1 .

- The last step is the calculation of limit (final) supermatrix $\bar{W}^{\infty}$. This supermatrix can be calculated as acyclical weighted matrix as follows $\bar{W}^{\infty}=$ $\lim _{k \rightarrow \infty} \bar{W}^{k}$, where $\bar{W}^{\infty}$ is limit (final) supermatrix, $\bar{W}^{k}$ is weighted supermatrix without an existence cycle, and this supermatrix is $\mathrm{k}$ times amplified. Global weights are found in the first column considering the goal.

\section{Regression Analysis}

A simple regression analysis is used to study the relationship between two variables. It is used to predict the value of a variable based on the other variables. The predicted variable is called dependent (or outcome, explanatory, and so on). The variable used to predict the explanatory variable is independent and is called explanation (sometimes control, predictor, and so on), (Hančlová, 2015). A simple equation of linear regression is:

$$
y=\beta_{0}+\beta_{1} x_{1}+. . \beta_{n} x_{n}+e,
$$


where $\beta_{0}, \beta_{1}$ and $\beta_{n}$ are parameters estimated by least squares approximation, $x_{1}$ and $x_{n}$ are predictor (independent) variables, $e$ is called the error term or disturbance in the relationship between response $y$ and control $x$.

Linear modelling has some assumptions (limitless). The error is a random variable with mean of zero conditional on the explanatory variables. The predictors (independent variable) are linearly independent. The errors are uncorrelated, which means the covariance matrix of errors is diagonal. The variance of error is constant in time during the observations, it is called homoscedasticity.

One of common methods of estimation is ordinary least squares (OLS).

\section{Ordinary Least Squares - Parameter Estimation Method}

In statistics, OLS is a type of estimation method used in the case of a classic linear regression. Ordinary least squares chooses the parameters of a linear function of a set of explanatory variables using the principle of minimizing the sum of squares. The minimizing sum of squares are the differences between the observed (dependent variable) across the dataset and those predicted by the linear function (Wooldridge, J. M., 2013).

The important thing is that the OLS estimator is consistent when the independent variables are exogenous, and where the errors are homoscedastic and serially uncorrelated. Under the mentioned conditions, the OLS method can simplify the calculation, provided there is minimum-variance at normal distribution. The estimation of the first parameter can be written as:

$$
\widehat{\beta}_{0}=\bar{y}-\widehat{\beta}_{1} \bar{x}
$$

where $\bar{y}$ is a sample average of observations of dependent variables, $\bar{x}$ is a sample average of observation, independent variable.

The estimated slope is:

$$
\widehat{\beta}_{1}=\frac{\sum_{i=1}^{n}\left(x_{i}-\bar{x}\right)\left(y_{i}-\bar{y}\right)}{\sum_{i=1}^{n}\left(x_{i}-\bar{x}\right)^{2}}=\frac{\operatorname{cov}(x, y)}{\operatorname{var}(x)} .
$$

Now, it is possible to make the sum of squared residuals, which are going to be minimized:

$$
\sum_{i=1}^{n} \widehat{e}_{i}^{2}=\sum_{i=1}^{n}\left(y_{i}-\widehat{\beta}_{0}-\widehat{\beta}_{1} x_{i}\right)=0,
$$

where $\sum_{i=1}^{n} \hat{e}_{i}^{2}$ is the sum of squared residuals, $y_{i}$ is $i$-th observation. 
The second step after estimation of parameters is the testing process. The most suitable tests, usually used for this type of estimation when the data are normally distributed, are T-test and F-test.

\section{Statistical Test - F-Test}

The F-test is based on hypothesis testing and is usually used to compare statistical models that have been fitted to a dataset, and to select the most suitable model. The F-test includes several assumptions, one of which is that data have to be normally distributed, all having the same process of deviations. F-test is used to compare two variances and plays an important role in the analysis of variance (ANOVA).

The statistic test in the case of F-test is the ratio of two scaled sums of squares which reflects different sources of variability. F-distribution under the null hypothesis means that the sums of squares should be statistically independent and each observation should lead to a scaled $\chi^{2}$ distribution.

The formula for the one-way ANOVA F-test statistic can be written as:

$$
F=\frac{e x \mathrm{var}}{u n \text { var }}
$$

where ex var is explained variable (known as between-group variability), un var is unexplained variability (sometimes called within-group variability).

The explained variance is following:

$$
\text { ex var }=\frac{\sum_{i=1}^{K} n_{i}(\bar{Y}-\bar{Y})^{2}}{K-1},
$$

where $\bar{Y}_{i}$ is the mean sample in the $\mathrm{i}$-th group, $n_{i}$ means the number of observations in the i-th group, $\bar{Y}$ is the overall number of units in the database, $K$ denotes the number of groups.

The unexplained variability can be written as follows:

$$
u n \operatorname{var}=\frac{\sum_{i=1}^{K} \sum_{j=1}^{n_{i}}\left(Y_{i j}-\bar{Y}_{i}\right)^{2}}{N-K}
$$

where $Y_{i j}$ denots $\mathrm{j}$-th observation in the $\mathrm{i}$-th out of $\mathrm{K}$ groups, $\mathrm{N}$ means the overall sample size. This F-statistic, which follows F-distribution, has degrees of freedom: $d_{1}=K-1$ and $d_{2}=N-K$. Thus, the null hypothesis is denoted as: 


$$
H_{0}: \sigma_{1}^{2}=\sigma_{2}^{2}
$$

and the null hypothesis is compared to the alternative (in the case of two-tailed test):

$$
H_{0}: \sigma_{1}^{2} \neq \sigma_{2}^{2}
$$

\subsection{Data}

The database for evaluation and verification of the insurance market consists of key insurance indicators in the period from 2006 to 2016 (CAP, 2006-2016). The mentioned indicators are used for example by the Czech Insurance Association and OECD for the evaluation of the insurance market level.

Qualitative and quantitative indicators of the assessment of the level of the insurance market are taken into account for the purposes of the article. The following indicators are included among qualitative indicators according to a subjective opinion of an expert: insurance penetration (IP) and claims ratio (CR). The following indicators are included among quantitative indicators: gross premium (GP), insurance benefit (IB), number of insurance contracts (IC), average insurance premium on one insurance contract ( $(\mathrm{IP})$, number of settled insurance claims (SIC), the average insurance benefit on one insurance contract ( $\varnothing \mathrm{IB})$, number of employees (NE), number of commercial insurance companies (CC), concentration of the insurance market (CM).

Table 3 Indicators of Assessment of the Insurance Market Level

\begin{tabular}{cc}
\hline Indicators & $\begin{array}{c}\text { Insurance penetration is calculated as the ratio of total insurance } \\
\text { premiums - or premiums at the market level - to the country's GDP }\end{array}$ \\
\hline IP & $\begin{array}{r}\text { Claims ratio is calculated as the ratio of claims/benefits incurred to } \\
\text { earned premiums }\end{array}$ \\
\hline CR & $\begin{array}{c}\text { Gross premium is premium payable under the relevant insurance } \\
\text { contracts in the relevant year. Part of this premium can only be income } \\
\text { in the following years }\end{array}$ \\
\hline IB & $\begin{array}{c}\text { Insurance benefit is the amount that is paid to the beneficiary when } \\
\text { they become entitled to insurance benefit as a result of the claim }\end{array}$ \\
\hline IC & Insurance contract is the number of insurance contracts \\
\hline ØIP & Average insurance premium on one insurance contract \\
\hline SIC & Number of settled insurance claims \\
\hline ØIB & Average insurance benefit on one insurance claim \\
\hline $\mathbf{N E}$ & Number of commercial insurance companies \\
\hline $\mathbf{C C}$ & Concentration of the insurance market \\
\hline CM & Soumber of employees \\
\hline
\end{tabular}

Source: Authors' own processing. 


\section{Results and Discussion}

The goal is to determine the weights and preferences of individual indicators of the assessment of the insurance market level using both AHP method and ANP method as well as regression analysis and to select the key indicators.

The first step in the insurance market level assessment is the selection of the indicators. The selected indicators areused for the insurance market level assessment by the Czech Insurance Association and OECD. The indicators are described in Figure 2. Next, the preferences of indicators are set, according to a subjective approach, using Saaty's method of multi-criteria decision making based on pairwise comparison and regression analysis.

\subsection{Indicator Preferences according to AHP and ANP Methods}

Both qualitative and quantitative indicators of the assessment of the level of the insurance market are taken into account for the purposes of the article. The following indicators are included among the qualitative indicators: insurance penetration (IP) and claims ratio (CR). The following indicators are included among the quantitative indicators: gross premium (GP), insurance benefit (IB), number of insurance contracts (IC), average insurance premium on one insurance contract (ØIP), number of settled insurance claims (SIC), the average insurance benefit on one insurance claim ( $\varnothing \mathrm{IB})$, number of employees (NE), number of commercial insurance companies (CC), concentration of the insurance market (CM). The preview of the indicator classification for the application of AHP is shown in Figure 2.

Figure 2 A Sample of AHP for the Purpose of Evaluation of the Insurance Market Level

The purpose (goal)

\begin{tabular}{ll}
\hline Qualitative indicators & Quantitative indicators \\
\hline Claims ratio & Gross premium \\
\hline Insurance penetration & Insurance benefit \\
\hline & The number of insurance contracts \\
\cline { 2 - 2 } & The average insurance premium \\
\cline { 2 - 2 } & The number of settled insurance claims \\
\cline { 2 - 2 } & The average insurance benefit \\
\cline { 2 - 2 } & The number of employees \\
\cline { 2 - 2 } & The number of commercial insurance companies \\
\cline { 2 - 2 } & Concentration of the insurance market \\
\end{tabular}

Source: Authors' own processing. 
The local and global weights based on Saaty's method of paired comparison are calculated. First, the local weights are established and so are the global weights. The global weights are calculated by both AHP and ANP methods. The analytic procedure and supermatrix method were used in the case of AHP. In the case of ANP, the supermatrix method was used.

Table 4 Preferences of Insurance Market Evaluation Indicators according to AHP and ANP Methods

\begin{tabular}{|c|c|c|c|c|c|}
\hline \multirow[t]{2}{*}{ Goal } & \multirow[t]{2}{*}{ Local } & \multirow[t]{2}{*}{ Groups } & \multirow{2}{*}{$\begin{array}{c}\text { Global - } \\
\text { analytic } \\
\text { method }\end{array}$} & \multicolumn{2}{|c|}{$\begin{array}{c}\text { Global - supermatrix } \\
\text { method }\end{array}$} \\
\hline & & & & AHP & ANP \\
\hline Qualitative & $75.00 \%$ & & & & \\
\hline Quantitative & $25.00 \%$ & & & & \\
\hline Insurance penetration & $33.33 \%$ & \multirow{2}{*}{$75.00 \%$} & $25.00 \%$ & $25.00 \%$ & $19.44 \%$ \\
\hline Claim ratio & $66.67 \%$ & & $50.00 \%$ & $50.00 \%$ & $38.89 \%$ \\
\hline Gross premium & $28.36 \%$ & \multirow{9}{*}{$25.00 \%$} & $7.09 \%$ & $7.09 \%$ & $11.81 \%$ \\
\hline Insurance benefit & $23.24 \%$ & & $5.81 \%$ & $5.81 \%$ & $9.68 \%$ \\
\hline $\begin{array}{c}\text { The number of insurance } \\
\text { contracts }\end{array}$ & $14.81 \%$ & & $3.70 \%$ & $3.70 \%$ & $6.17 \%$ \\
\hline $\begin{array}{c}\text { The average insurance } \\
\text { premium }\end{array}$ & $10.58 \%$ & & $2.64 \%$ & $2.64 \%$ & $4.41 \%$ \\
\hline $\begin{array}{l}\text { The number of settled } \\
\text { insurance claims }\end{array}$ & $9.31 \%$ & & $2.33 \%$ & $2.33 \%$ & $3.88 \%$ \\
\hline $\begin{array}{c}\text { The average insurance } \\
\text { benefit }\end{array}$ & $5.17 \%$ & & $1.29 \%$ & $1.29 \%$ & $2.15 \%$ \\
\hline The number of employees & $1.83 \%$ & & $0.46 \%$ & $0.46 \%$ & $0.76 \%$ \\
\hline $\begin{array}{c}\text { The number of commercial } \\
\text { companies }\end{array}$ & $4.02 \%$ & & $1.00 \%$ & $1.00 \%$ & $1.67 \%$ \\
\hline $\begin{array}{l}\text { Concentration of the } \\
\text { insurance market }\end{array}$ & $2.69 \%$ & & $0.67 \%$ & $0.67 \%$ & $1.12 \%$ \\
\hline$\sum$ & & $100.00 \%$ & $100.00 \%$ & $100.00 \%$ & $100.00 \%$ \\
\hline
\end{tabular}

Source: Authors' own processing.

From the qualitative view, the main influence on the insurance market level assessment was found in the claim ratio indicator. The local weight was $66.67 \%$. According to the quantitative indicator, the highest local strength was found in the gross premium indicator, where the influence strength was $28.36 \%$.

The next step focused on the calculation of the global weights according to the AHP and ANP methods. In the case of the AHP method, two ways of calculation were used: the analytic procedure and the method of supermatrix. The strongest influence was found in the claim ratio indicator, the strength was $50 \%$. According to the supermatrix method, the results were slightly different due to the feedback between subgroups. The order of preferences of the indicators remain the same, 
the values of the preferences are slightly different. E.g. for the above mentioned claims ratio, the weight was currently calculated at $38.89 \%$. A synergy effect of both methods was obvious: they can bring together diverse groups of decisionmakers with different perspectives to make a complex decision.

\subsection{Indicator Preferences according to Regression Analysis}

Multi-criterial assessment is a subjective method, where the preferences are determined based on subjective feelings of a decision-maker. The final order of the indicators of the assessment of the insurance market level using AHP and ANP methods was verified by regression analysis. Using regression analysis it is possible to study not only the relationship between dependent and independent variables, but also to detect the strength of this relationship. In this part, the indicators were divided into two groups: qualitative and quantitative. The regression model was created for each group. The models were estimated without constant, in order to obtain more accurate results.

Insurance penetration and claim ratio were included in the group of qualitative indicators. It is necessary to choose a dependent variable in this step. Claim ratio appears the most suitable indicator. Insurance penetration remains an independent variable. It is advisable to test the results of model estimation by F-test. The model was verified using F-test, which is used for verification of statistical significance of the model as a whole. According to the results of this test, the model is statistically significant, see Table 5 .

Table 5 The Result of F-test

\begin{tabular}{lccccc}
\hline \multicolumn{7}{c}{ ANOVA $^{\mathbf{a}, \mathbf{b}}$} \\
\hline \hline Model 1 & $\begin{array}{c}\text { Sum of } \\
\text { Squares }\end{array}$ & df & $\begin{array}{c}\text { Mean } \\
\text { Square }\end{array}$ & F & Sig. \\
\hline Regression & 4.973 & 1 & 4.973 & 637.809 & $0.000^{c}$ \\
\hline Residual & 0.125 & 16 & 0.008 & & \\
\hline Total & $5.097^{d}$ & 17 & & & \\
\hline
\end{tabular}

Source: Authors' own processing.

In the case of the quantitative indicators, the selection process was more complicated. There are nine quantitative indicators. Gross premium was selected as a dependent variable and other indicators represent independent variables. The dependent variable was chosen based on its statistical significance.

In this part, the regression model for the dependent variable of gross premium and other explanatory variables was estimated. Statistical significance was verified by F-test, the same as in the previous model. Based on the results of this test, it is possible to confirm the statistical significance of the model as a whole. The results of F-test are presented in Table 6. 
Table 6 The result of F-test

\begin{tabular}{lcccccc}
\hline \multicolumn{5}{c}{ ANOVA } \\
\hline \hline Model 2 & Sum of Squares & df & Mean Square & F & Sig. \\
\hline Regression & 277737851214752832.000 & 8 & 34717231401844104.000 & 21740.991 & .000 \\
\hline Residual & 14371704054231.875 & 9 & 1596856006025.764 & & \\
\hline Total & $277752222918807072.000^{d}$ & 17 & & \\
\hline
\end{tabular}

Source: Authors' own processing.

In the process of the evaluation of indicators, the value of significance determined by the statistical significance of each variable was taken into account. The value of significance should be maximum around 0,05 for a significance level of $95 \%$. When the value is higher, the indicator is considered statistically insignificant.

Table 7 Final regression model

\begin{tabular}{lccccc}
\hline \multicolumn{7}{c}{ Coefficients $^{\text {a.b }}$} \\
\hline Model & $\begin{array}{c}\text { Nonstandardized } \\
\text { Coefficients }\end{array}$ & $\begin{array}{c}\text { Standardized } \\
\text { Coefficients }\end{array}$ & t & Sig. \\
\hline IB & $\mathrm{B}$ & Std. Error & Beta & .000 \\
\hline IC & 1.806 & .088 & .999 & 20.519 & .000 \\
\hline ØIP & 5.211 & .227 & .958 & 22.925 & .000 \\
\hline SIC & 25102.442 & 1388.655 & 1.055 & 18.077 & .000 \\
\hline ØIB & -56.205 & 2.776 & -1.074 & -20.248 & .000 \\
\hline & -4216.859 & 250.568 & -.931 & -16.829 & .000 \\
\hline
\end{tabular}

Source: Authors' own processing.

The final order of the indicators was determined on the basis of the correlation matrix results. Correlation analysis is shown in Table 8.

Table 8 Correlation Matrix of Variables

\begin{tabular}{|c|c|c|c|c|c|c|c|}
\hline \multicolumn{8}{|c|}{ Correlations } \\
\hline & & GP & IB & IC & SIC & $\varnothing \mathrm{IP}$ & $\varnothing \mathrm{IB}$ \\
\hline GP & $\begin{array}{l}\text { Pearson } \\
\text { Correlation }\end{array}$ & 1 & $.882^{* *}$ & $.976^{* *}$ & $.784^{* *}$ & $.841^{* *}$ & $.871^{* *}$ \\
\hline & Sig. (2-tailed) & & .000 & .000 & .000 & .000 & .000 \\
\hline & $\mathrm{N}$ & 17 & 17 & 17 & 17 & 17 & 17 \\
\hline \multirow[t]{3}{*}{ IB } & $\begin{array}{l}\text { Pearson } \\
\text { Correlation }\end{array}$ & $.882^{* *}$ & 1 & $.906^{* *}$ & $.901^{* *}$ & $.623^{* *}$ & $.950^{* *}$ \\
\hline & Sig. (2-tailed) & .000 & & .000 & .000 & .008 & .000 \\
\hline & $\mathrm{N}$ & 17 & 17 & 17 & 17 & 17 & 17 \\
\hline IC & $\begin{array}{l}\text { Pearson } \\
\text { Correlation }\end{array}$ & $.976^{* *}$ & $.906^{* *}$ & 1 & $.789^{* *}$ & $.708^{* *}$ & $.895^{* *}$ \\
\hline
\end{tabular}




\begin{tabular}{|c|c|c|c|c|c|c|c|}
\hline \multicolumn{8}{|c|}{ Correlations } \\
\hline & & GP & IB & IC & SIC & $\varnothing \mathrm{IP}$ & $\varnothing \mathrm{IB}$ \\
\hline & Sig. (2-tailed) & .000 & .000 & & .000 & .001 & .000 \\
\hline & $\mathrm{N}$ & 17 & 17 & 17 & 17 & 17 & 17 \\
\hline \multirow[t]{3}{*}{ SIC } & $\begin{array}{l}\text { Pearson } \\
\text { Correlation }\end{array}$ & $.784^{* *}$ & $.901^{* *}$ & $.789^{* *}$ & 1 & $.589^{*}$ & $.725^{* *}$ \\
\hline & Sig. (2-tailed) & .000 & .000 & .000 & & .013 & .001 \\
\hline & $\mathrm{N}$ & 17 & 17 & 17 & 17 & 17 & 17 \\
\hline \multirow[t]{3}{*}{ ØIP } & $\begin{array}{l}\text { Pearson } \\
\text { Correlation }\end{array}$ & $.841^{* *}$ & $.623^{* *}$ & $.708^{* *}$ & $.589^{*}$ & 1 & $.624^{* *}$ \\
\hline & Sig. (2-tailed) & .000 & .008 & .001 & .013 & & .007 \\
\hline & $\mathrm{N}$ & 17 & 17 & 17 & 17 & 17 & 17 \\
\hline \multirow[t]{3}{*}{$\varnothing I B$} & $\begin{array}{l}\text { Pearson } \\
\text { Correlation }\end{array}$ & $.871^{* *}$ & $.950^{* *}$ & $.895^{* *}$ & $.725^{* *}$ & $.624^{* *}$ & 1 \\
\hline & Sig. (2-tailed) & .000 & .000 & .000 & .001 & .007 & \\
\hline & $\mathrm{N}$ & 17 & 17 & 17 & 17 & 17 & 17 \\
\hline \multicolumn{8}{|c|}{ **. Correlation is significant at the 0.01 level (2-tailed). } \\
\hline$* . \mathrm{C}$ & lation is signific & the 0 . & level $(2$ & iled). & & & \\
\hline
\end{tabular}

Source: Authors' own processing.

Based on the results of the regression analysis, it is clear that the order of qualitative indicators is the same as in the case of multi-criteria decision making, but the order of quantitative indicators is slightly different.

The final order according to regression analysis is shown in Table 8. Thus, we can state that for the assessment of the insurance market level, the most important indicator is claim ratio, the second, but still important is insurance penetration, and the third is gross premium.

Table 9 gives an overview of the final ranking of the indicators identified by all the methods applied. The order of preference of the indicators according to the AHP and ANP methods is identical, they differ only slightly in the values of preferences, which reflects the consideration of network links between the indicators and the groups of indicators by the ANP method. The AHP method does not take the network links into account. A similar order of preferences is achieved when using the regression analysis method.

Table 9 also shows the range of key indicators (order 1 to 5), the band of indicators with a medium level of preference (order 6 to 8 ) and the band of indicators with a low level of preference (order 9 to 11). Thus, the group of key indicators for the insurance market assessment would consist of claims ratio, insurance penetration, gross premiums, insurance benefits, and the number of insurance contracts. 
Table 9 Final Order of Variables

\begin{tabular}{cccc}
\hline Indicators & $\begin{array}{c}\text { Order } \\
\text { AHP }\end{array}$ & $\begin{array}{c}\text { Order } \\
\text { ANP }\end{array}$ & Order RA \\
\hline Claims ratio & 1 & 1 & 1 \\
\hline Insurance penetration & 2 & 2 & 2 \\
\hline Gross premium & 3 & 3 & 3 \\
\hline Insurance benefit & 4 & 4 & 5 \\
\hline The number of insurance contracts & 5 & 5 & 4 \\
\hline The average insurance premium & 6 & 6 & 7 \\
\hline The number of settled insurance claims & 7 & 7 & 6 \\
\hline The average insurance benefit & 8 & 8 & 11 \\
\hline The number of commercial insurance & 9 & 9 \\
\hline Conmpanies & 9 & 10 & 10 \\
\hline The number of employees & 10 & 11 & 8 \\
\hline
\end{tabular}

Source: Authors' own processing.

\section{Conclusions}

The aim of this article was to determine the preferences of indicators of evaluation of the insurance market level using multi-attribute AHP and ANP methods on the basis of Saaty's method of paired comparison and regression analysis, and to select the key indicators.

The multi-attribute decomposition AHP and ANP methods on the basis of Saaty's method of paired comparison were described. Then the analytic method and supermatrix were used. It was found that both approaches to AHP and ANP methods lead to the same results regarding the order of preferences of indicators. Subsequently, the final order of preferences of indicators was verified by the regression model. In the process of the regression analysis, two models were estimated. First, the model with qualitative variables, where the dependent variable was claim ratio, was estimated. The second regression model was estimated using quantitative indicators, where dependent variable was gross premium. The results showed that the final order based on AHP method and regression analysis for qualitative indicators was the same, the order of quantitative indicators was only slightly different.

The most important indicators that can be described as the key indicators with a high preference (above 5\%) are claim ratio (38.89\%), insurance penetration $(19.44 \%)$, gross premiums $(11.81 \%)$, insurance benefits $(9 \%)$, and the number of insurance contracts $(6.17 \%)$. The indicated percentages were determined by the ANP method. The indicators of medium preference, with a preference rate of more than $3 \%$, include the indicator of average insurance premium on one insurance contract, the number of settled insurance claims, and the average insurance benefit on one insured claim. The category of low-preferred indicators with a preference 
rate of less than $3 \%$ consists of the indicator of the number of commercial insurance companies, concentration of the insurance market, and the number of employees.

\section{Acknowledgments}

This paper was supported by the SGS Project VŠB - TU Ostrava SP2018/154 "Finanční rozhodování podniků a finančních institucí za rizika".

\section{References}

Arena, M. (2008). Does Insurance Market Activity Promote Economic Growth? A Cross-Country Study for Industrialized and Developing Countries. The Journal of Risk and Insurance, 75(4), pp. 921-946.

Bernoulli, D. (1954). Speciman theorie novae de mensura sortis. Connentarii Academiae Scientiarum Imperialis Petropolitanae 5(1738), pp. 175-192. [English translation by L. Somera: Exposition of a New Theory of Risk Evaluation, Econometrica 22, pp. 23-36]

Borovcová, M. and Špačková, A. (2017). Indicators preference determination of the level insurance market assessment by applying the AHP and ANP decomposition multi-attribute methods. In: Finance and performance of firms in science, education and practice: proceedings of the 8th international scientific conference: April 2627, 2017, Zlín, Czech Republic. Zlín: Tomas Bata University in Zlín, pp. 98-109.

Czech Insurance Association - CAP (2006-2016). Výroční zprávy ČAP (Annual reports). Available at: http://www.cap.cz/o-nas/vyrocni-zpravy.

Fotr, J., Dědina, J. and Hrůzová, H. (2010). Manažerské rozhodování. $2^{\text {nd }}$ rev. ed. Praha: Ekopress.

Hančlová, J., Chytilová, L., Ramík, J., Toloo, M., Zapletal, F., Babaee, S., Shen, Y. and Hermans, E. (2015). Optimization problems in economics and finance. Ostrava: VŠB-TU Ostrava.

Kwon, W. J. and Wolfrom L. (2016). Analytical tools for the insurance market and macro-prudential surveillance. OECD Journal: Financial Market Trends, published online first, 2016/1, pp. 1-47.

Pradhan, R. P., Arvin M. B. and Norman N. R. (2015). Insurance development and the finance-growth nexus: Evidence from 34 OECD countries. Journal of Multinational Financial Management, 31(2015), pp. 1-22.

Ramík, J. (1999). Vícekriteriální rozhodování - analytický hierarchický process $(A H P)$. 1st ed. Karviná: Slezská univerzita v Opavě.

Pareto, V. (1971 (1906)). Manual of political economy (manuale di economia politica), Kelley, New York.

Saaty, T. L. (1980). The analytic hierarchy process: planning, setting priorities, resource allocation. New York, McGraw-Hill International Book Co. 
Saaty, T. L. (2012). Decision making form leaders: the analytic hierarchy proces for decisions in a complex world. 3rd rev. ed. Pittsburgh: RWS Publications.

Saaty, T. L. (2006). Fundamentals of decision making and priority theory with the analytic hierarchy process. 1st ed. Pittsburgh: RWS Publications.

Saaty, T. L. (2010). Mathematical principles of decision making: generalization of the analytic network process to neural firing and synthesis. 1st ed. Pittsburgh: RWS Publications.

Saaty, T. L. (2009). Theory and applications of the analytic network process: decision making with benefits, opportunities, costs, and risks. 3rd ed. Pittsburgh: RWS Publications.

Wooldridge, J. M. (2013). Introductory econometrics: a modern approach. 2nd ed. South- Western, Cengage Learning.

Zmeškal, Z., Dluhošová, D. and Tichý, T. (2013). Finanční modely: koncepty, metody, aplikace. 3rd rev. ed. Praha: Ekopress.

Zmeškal, Z. (2009). Vícekriteriální hodnocení variant a analýza citlivosti při výběru produktü finančních institucí. Financial management of firms and financial institutions. 1st ed. Ostrava: VŠB - Technická univerzita Ostrava. 